International Conference on

"Africa: The Challenge of

Economic Recovery and

Development"

Abuja, Nigeria

15-19 June 1987

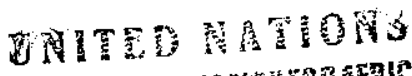

$62+74$

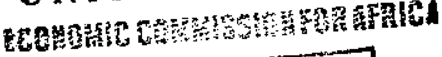

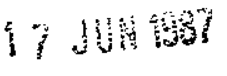

L I B R R Y

ADUISABABA
$\mathrm{ECA} / \mathrm{CERAD} / 87 / 20$

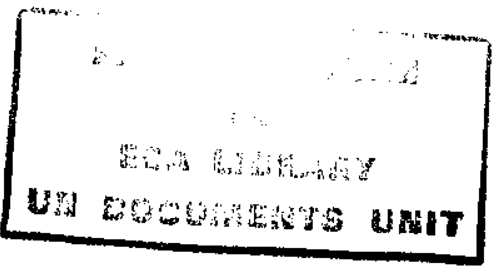

SUB-SAHARAN AFRICA AND THE INTERNATIONAL COMMUNITY

by

\author{
Joseph C. Wheeler \\ Organization for Economic Cooperation \\ and Development*
}

\footnotetext{
*As Chairman of the Development Assistance Committee of the Organisation for Economic Cooperation and Development. I chair a group of 19 donors which together provided in 1985 about $\$ 30$ billion in official Development Assistance. The chairman writes on his own authority and his views do not necessarily represent the views of either the organisation for Economic Cooperation and Development or of the individual Members of the Development Assistance Committee. The Members of the Development Assistance Committee are: Australia, Austria, Belgium, Canada, Commission of the European Communities, Denmark, Finland, France, Germany, Ireland, Italy, Japan, the Netherlands, New zealand, Norway, Sweden, Switzerland, the United Kingdom and the United States.
} 
I am asked to look at Sub-Saharan Africa from the point of view of the aid donor community. Each African country has its unique natural endowments, economic circumstances and history and therefore there are severe limitations on any process of generalisation. Likewise, donors vary widely in economic capability, geo-political concerns and approaches to development. Nevertheless, it is difficult to avoid generalizing about both Africa and the donor community. One hopes the reader will be forgiving if some generalisations do not fit particular country or donor circumstances.

The Challenge

The world has come to recognise the enormous challenge facing sub-Saharan Africa. Over the next three decades Africa must triple food output to meet the needs of an unusually fast-growing population. This come after a generation when per capita food production went down an average of more than 1 per cent a year.

Within thirty years Africa must increase the number of places for firstyear primary school students to 30 million. DAC countries today contain about 700 million people compared with less than 500 million in Sub-Saharan Africa, but have only 10 million children entering school each year. The proportion of chilaren to total population in Africa is four times that of the DAC countries.

On the average Sub-Saharan Africa still loses one out of every ten new-born babies in the first year. While tinis is substantially lower than the figure for twenty years aso, it is generally accepted that no country needs to have an infant mortality rate this high. Arrican countries will be making a concerted effort to improve the health of their citizens in the decades ahead.

Africa faces critical problems cf environmental deterioration, including deforestation, desertification and soil loss, which will gain increasing attention from decision-makers over the coming decades.

Over the next 30 years Africa will need employment opportunities for another 300-400 million working-age people. Since most of these jobs will be in the private sector, African governments will give increasing attention to the policy environment and infrastructure resources needed to encourage 
ECA/CERAD $/ 87 / 20$

Page 2

With all of these long-term development challenges, Africa enters the period with its hands at least partly tied by a combination of conditions arising from an awful drought, earnings diminished by sluggish world growth in trade and structural changes in commodity markets and the need to service an accumulation of debt.

There is little I can add to what others have said about the financial conditions of African countries. Surely it would help if world growth accelerated, if protectionism were diminished, if interest rates went down, and if terms of trade improved. Indeed, anyone concerned about African development knows that these are often most important factors. But most of these factors will be affected by decisions unrelated to policies designed specifically for Africa. It is resource flows which can be affected by donor decisions and to a considerable extent by the African countries themselves. I will therefore concentrate on volume of flows, the efficiency of their use and their role in supporting African country structural adjustment.

Resource Flows to Africa

Most of the resources to cope with Africa's monumental challenges will come from Africa itself. But substantial outside financing will also be needed. Let us look at the current situation on resource flows to Africa as reflected in OECD statistics. See Pable 1 for a summary of available data on total net resource flows to Sub-Saharan Africa.

In the Development Assistance Committee (DAC) we divide "total net resource flow" into three major categories: official development finance; total export credits; and private flows. Total net resource flows to subSaharan Africa in 1985 are estimated to have been about $\$ 16$ billion*. This amount is from all sources, public and private, and inclules aid not only from DAC countries but also from OPEC and CMEA countries. I will discuss the components of this total working up from the bottom of Table 1 .

*For 1986 the figure is estimated to be $\$ 18$ billion. Because of the significant change in exchange rates in real terms, however, this represents a modest decrease from the 1985 level. 
ECA $/$ CERAD $/ 87 / 20$

Page 3

\section{Private Flows}

Total private flows in 1985 were about $\$ 2.5$ billion. Commercial private flows were only $\$ 1.1$ billion. Commercial flows were down from levels which in 1979 and 1981 exceeded $\$ 3.5$ billion. The reduced levels reflect the private sector's more pessimistic perception of creditworthiness in light of very high levels of indebtedness, reductions in commodity prices and other economic circumstances. One could guess that private flows would be unlikely to reach earlier levels for several years. Yet, in the long run, private commercial flows will be critical to the financing of rapid African growth.

The first commercial private flows to recover are likely to be those owned by Africans themselves. Exchange rates, interest rates, prices, marketing systems, and other factors will affect profitability and when these become positive Africans are likely to repatriate funds now lodged in developed country banks or stock markets. When Africans find it profitable to invest in Africa, the rest of the world will follow.

Note that under "other private" flows OECD includes primarily grants by non-governmental organisations (NGOs). These are privately contributed grant funds which have tended to increase over the years. Now estimated by the OECD Secretariat at nearly $\$ 1$ billion for sub-Saharan Africa, they represent a welcome and significant supplement to official Development Assistance.

\section{Total Export Credits}

Export credits in 1985 are estimated to have been about $\$ 0.6$ billion. This is down from a level reached in the $1979-82$ period of about $\$ 2$ billion. Again, these reductions reflect a perception of lowered creditworthiness, in this case by government agencies rather than by the private sector. The reduction probably also reflect less demand by sub-Saharan countries for non-concessionally funded imports. It is unlikely that either borrowers or lenders will press for higher levels until debt servicing-export ratios are greatly improved. 
ECA/CERAD $/ 87 / 20$

Page 4

Official Development Finance

Total official Development Finance (ODF) is made up of two categories: official Development Assistance (ODA), and other official development finance (other ODF). Total ODF in 1985 was about $\$ 12.9$ billion. This was the highest level ever reached. (Early estimates for 1986 suggest a further increase in total ODF to about $\$ 15.0$ billion or about $\$ 13.1$ billion at 1985 prices and exchange rates.' The portion of the 1935 Ievel which is 1 isted in OECD statistics as "other ODF" is $\$ 1.8$ billion. This represents financing which does not meet the concessionality criteria of official Development Assistance. The most important example would be financing from the regular funds of the world Bank (as opposed to the very concessional IDA funds). Although lower than 1984, the $\$ 1.8$ billion level was at roughly the same level as had been made available under this category over the four earlier years.

Official Development Assistance, on the other hand, represented "ll.l billion of the $\$ 12.9$ billion total. This was higher than earlier levels. Representing, as it did in 1985, 70 per cent of total resource flows, in the short run it is the most important factor. The point to underline is that this concessional assistance has been a steady source and an increasing source of funding for ffrica while private commercial flows and export credits have tluctuated sharply in light of changing economic circumstances. Furthermore, these funds are provided on grant or very concessional terms.

The prospects for future official Development Assistance to Sub-Saharan Africa are for modest continuing increases. The portion of world-wide aid going to Africa has increased from about 20 per cent to about 30 per cent over the past decade. We tentatively guess that the proportion of total bilateral aid going to Sub-Saharan Africa will not continue to increase substantially. However, since we estimate total ODA will increase moderately at perhaps 2 per cent per year, total ODA flows to Sub-Saharan Africa should: also increase moderately,

It is worth looking at aid flows from the point of view of the recipients. Taking DAC bilateral, OPEC and multilateral ODA together, OECD statistics suggest that Sub-Saharan Africa is now receiving 5 per cent of its GNP from aid (see Table II). For low-income Sub-Saharan Africa ovar 
ECA/CERAD/87/20

Page 5

10 per cent of GNP comes from aid. For some countries the proportion is much higher. For example, the sahel group is receiving about 20 per cent of GNP in aid, and somalia is receiving 24 per cent of GNP in aid. Thus reasonable questions can be raised about the implications of such high levels of aid dependency if extended for a long time.

By way of perspective total GNP in Sub-Saharan Africa is less than the GNP of Spain. Also by way of pexspective, India, with substantially more people than Sub-Saharan Africa and a per capita income only slightly higher than the Sub-Saharan low-income country average, received net ODA in 1985 of about $\$ 1.5$ billion - compared with a net ODA of $\$ 11.1$ billion for Sub-Saharan Africa.

\section{African Debt}

Debt is an important issue in Africa although African debt represents less than 10 per cent of the world-wide portfolio. In a number of individual countries the requirements for debt service financing are so high that special forms of relief will clearly be needed. Total Sub-Saharan debt, both short and long-term, at the end of 1986 was about $\$ 95$ billion (see Table III). However, aggregating debt figures for the continent is of questionable usefulness. For many countries debt servicing is being successfully managed. For others the best we can say is that the problem is being put off. Many of the important decisions related to debt renegotiations are arrived at in the Paris Club for official debt and the London Club for private.

The DAC has taken the position that those making decisions about debt should be well informed about the status of structural adjustment programmes and the availabilities of other resources. The point here is that, in connection with any one country situation, in addition to the country government there are a number of circles of decision-making, including the increasingly well coordinated structural adjustment discussions with the World Bank and IMF, the debt discussions in the Paris and London clubs, the processes of Round Tables and Consultative Groups, and the individual decision-making of each bilateral donor. since debt decision-making is 
made in such a wide vaxiety of places, the minimum we can ask of ourselves is that all decision-makers have the best possible understanding of the requirements and of what oiner decision-makers are doing.

There seems to be a widening acceptance that in some cases actions will be required which go beyond recent practice. For example, the Communique of the April 10, 1987 Washington meeting of the Development Committee, chaired by the Honourable B.T.G. Chidzero, Minister of Finance, Economic Planning and Development of Zimbabwe, recognised that many countries, "especialy in Sub-Saharan africa, sace severe problems of indebtedness. Ministers stressed the need for larger concessional flows and agreed that for many of these countries additional measures were needed to improve their capacity to service their debts and at the sane time undertake growth-oriented programs".

Similariy, the Interim Committee of the Board of Governors of the International Monetary Fund on April 8,1987 said the following:

"Committee members expressed special concern about the plight of low-income countries. The Committee emphasized that it is crucial for these countries to implement major reforms which, to be fully effective, will reed to be accompanied by additional financing on concesssioal terms. In this connection, the progress with operations under the Fund's structural Adjustment Facility was welcomed. Committee members noted the forthcoming review by the Executive Board of the Structural hijustment tacility and they expressed their hope that arrangements under the Faciljty would serve to elicit from bilateral and multilateral donors the necessary additioal financial support. In this general context, the committee a!so urged creditor gnvernments, as a matter of priority, to consider means for granting exceptional financial relief with respect to official credits in cases, including particularly sub-Saharang Africa, where such relief is necessary to support and encourage far-reaching economic reforms in highly indebted low-income countries.

"Close cooperation between the Fund and the World Bank was welcomed. Committee members noted that increased lending from multilateral development banks had contributed importantly to debtor country 
financing. They noted with appreciation the continuing efforts and new initiatives of the paris club to tailor rescheduling agreements to the circumstances of individual countries and stressed the importance of necessary flexibility on the part of export credit agencies in resuming or increasing cover for countries that are implementing comprehensive adjustment programs."

While the ministers in the Development and Interim Committees. have so far not been very precise on what additional measures might be taken, the recognition of the problem is a welcome step. Since the Development and Interim Committees met in April the Paris club has been continuing the dialogue. Already the Paris Club has agreed that in some cases grace periods can be extended.

Most recenty the Council of the OECD meeting at Ministerial Level in Paris on May 13, 1587, after declaring on issues of improving growth prospects, macro-economic policies and structural adjustment policies in their own countries, spoke of relatios with developing counries. Inter alia, they said:

"Even more constraining are debt problems among low-income countries. Proposals have recently been made by OECD countries for additional action to reduce the debt servicing burden of the poorest countries, especially in sub-Saharan Africa, undertaking strong growthoriented adjustrient progremmes. Early results from the current discussions among creditor governments will be urgently sought.

"For poorer developing countries, provision of adequate concessional finance is essential. OECD countries' record in this respect is already substantial but should be further enhanced. The volume and forms of aid must be commensurate with the growing requirements of policy reform programmes and sroader development efforts. The new DaC guiding principies for using aid to support improved development policies and programmes and strengthening aid coordination with developing countries are welcomed". 
It is quite clear that the international community will be giving these issues more urgent attention in the coming months. In its further consideration of the Sub-Saharan debt issue, it seems likely that special attention will be given to the problems of about a dozen countries which are carrying out structural adjustment programmes and which have debt-servicing/export ratios in excess of 25 per cent. No combination of measures so far put forward will adequately deal with the problems of accumulated debt of at least some of these countries.

\section{Supporting Structural Adjustment}

Over the past several years, a majority of African countries have embarked on structural adjustment programmes. of course, no country developed or developing - can escape the need for structural adjustment. slow agricultural growth and unmanageable debt were the symptoms which signalled the need for special action in many African countries. The resolve of the African community toward reform was well reflected in the United Nations Programme of Action for African Economic Recovery and Development 1986-1990 adopted by the General Assembly in June 1986 and has been demonstrated in the practical steps taken since that time, usually in close consultation with the IMF and the World Bank as well as with many other donors. These reform programmes often require forms of aid which many donors have found it difficult to provide. I have in mind the need for quick-disbursing funds for spare parts and raw materials needed to achieve fuller utilisation of existing capacity - both public and private and including industry, agriculture and public infrastructure. Exchange rate reforms, including foreign exchange auctions designated to provide fully adequate funds to the private sector at realistic exchange rates have also needed financing. Some donors have made very special efforts to accommodate their policies and procedures to be responsive to the special needs of structural adjustment programmes. Others have so far abstained from this kind of support on the grounds that their resources are minimal or because of strong preferences for utilising their scarce funds in support of a project portfolio. A recent important event has been Japan's May, 1987 announced intention to provide significant additional support to African low-income countries. It is not clear what the requirements will be for additional quick-disbursing funds. Many African countries have found adequate levels 
ECA/CERAD $/ 87 / 20$

Page 9

of sufficiently flexible money to provide the support they needed for structural adjustment. others have not. I believe it will be important to bring an increasing sense of urgency to the process of identifying unmet needs for structural adjustment as a basis for further consideration by donors and recipients of how aid can be used most effectively to support structural adjustment.

In discussions in the $D A C$ it has been brought to our attention that the donor countries from time to time lack discipline in keeping within agreed investment schedules. It is argued that after long and careful analysis African countries have adopted lists of highest priority projects which should receive first call on available financing. In one case. I was told that a donor country agreed with an African country to proceed with a project not on the priority list only weeks following agreement on the list within a structural adjustment process. of course, the obvious point is that it takes two to make such an agreement and that the African country, being the requesting country, must take its full share of responsibility. since one cannot doubt the seriousness of the African country minister of finance in putting the list forward on behalf of his government, this example points up the need for systems within African governments of horizontal coordination of aid negotiations -- avoiding a situation where aid is negotiated by a number of competing ministries dealing outside a policy framework with donors who themselves may not have been very close to the structural adjustment negotiations. Also, it is clear that to the extent donors are brought into structural adjustment discussions they will be more committed to the results. Anyway, donors recognise the need to respect the discipline of the structural adjustment process. This was agreed at last December's DAC High-Level Meeting which emphasized "the need for continuing discipline by both recipients and donors in adhering to carefully appraised and productive investment programmes...". (See Appendix 1 for DAC's agreement on "Aid for Improved Development Policies and Related Aspects of Aid Coordination").

Over the past two years of debate about structural adjustment a consensus has been reached that our goal is adjustment with growth. Beyond that is the idea of "adjustment with a human face". DAC Members expressed their 
$\mathrm{ECA} / \mathrm{CERAD} / 87 / 20$

Page 10

view in their guiding principles for aid coordination (cited above) as follows: DAC Members "agree that structural adjustment programmes should take fully into account equity and income distribution issues and would like to see more explicit addressing of budget and strategy issues in human resources questions such as education, health and population, as well as environment". In practice this has proved difficult to achieve. In structural adjustment negotiations inevitably the critical issues such as exchange rate policy, budget levels, and price policy have taken the time and attention of the participants. While statistics on the impact of structural adjustment on education, health and nutrition are difficult to gather, it seems to be generally agreed that adjustment has often slowed growth in these areas or even caused backward movement. The damage is magnified by the fact that progress in these areas is generally correlated with progress in achieving a demographic transition which, in turn, is relevant to achieving an environmental balance. African governments and donors share an interest in giving this problem more attention.

Issues for Donors and Recipients in Aid Administration

With Official Development Assistance representing over 10 per cent of low-income fifrica's GNP, we must ask ourselves how we can make the best use of these precious funds. The first question any observer must ask is whether or not the African countries are organised to receive this amount of assistance.

In African governments a high priority is placed on the staffing of central banks and ministries of finance. It is not so immediately apparent that governments place equally high priority on the staffing of aid negotiations. Some of us who have worked in other parts of the world have seen governments appoint as aid coordinators senior civil servants of calibre and rank comparable to the person assigned to manage finance and the central bank. This person usualiy has direct access to a senior minister and meets frequently with the prime minister. Yet in Africa, where aid dependence is much higher, there is a perception in the donor community that aid coordination and negotiation are dealt with as lower priorities. 
ECA/CERAD $/ 87 / 20$

Page 12

needed funds for operations one way or another. Funds are then provided to a lower-priority project because an unused project would become a political embarrassment both at home and abroad.

If consulted, a ministry of finance would be particularly concerned about the budgetary implications of a project. It would also be concerned about financial poliry issues and would look to see whether procurement procedures were followed which would achieve good value for money. Further, a ministry of finance would know that a short route to insolvency is borrowing foreign exchange to finance a series of unproductive projects. But, if not consulted, these considerations might not be given appropriate attention.

A ministry of planning, looking to the longer run, besides issues of interest to the ministry of finance, would be particularly interested in the relation of projects to longer-term planning criteria and to the sustainability aspects of projects. They would ask whether a project simply "provides a fish" or rather "teaches how to fish". A ministry of planning might well be interested in whether a health project would actually change the health condition of the population as opposed to providing a high-cost service to a few people in the capital city. They would probably be more interested in a public health oriented project than a curative oriented project. But, if not consulted, their concerns might not be considered.

Low quality decision-making by the donor and recipient communities can never be justified. But in a time when an especially high degree of austerity is forced upon; us, the need to assure the best possible quality of decision-making within a coordinated process where good development criteria are adequately considered is minifest.

One of the special attributes of African assistance is the large number of sources. It is not untypical these days for a relatively small African country to be receiving official Development Assistance from some thirty official aid agencies in addition to an untold number of non-governmental agencies. In the Development Assistance Committee we, have been giving increasing attention to the question of coordination. Whether coordination is spoken of, we find ourselves coming back to the fundamental point that we are providing assitance to sovereign countries who should be making their 
ECA/CERAD $/ 87 / 20$

Page 13

own decisions and therefore should be at the centre of the coordination process. This is why it is so critically important that sub-Saharan countries themselves organise more and more effectively to deal with the conor community.

Certainly there is no one "right" way to organise to receive aid more efficiently. I do not argue that all decisions must be made in one office. Rather, I argue that aid decisions should be made within a policy framework determined by the receiving government and that decisions should be made which are consistant. It is no longer satisfactory for governments to receive aid with conflicting policy prescriptions. We recall the case in one country where, following the criteria of three different donors, three different credit policies were being implemented simultaneously. It would be to African countries' advantage to develop aid coordination capacity able to represent views vigorously to the donors. At the same time donors' willingness to adjust policies or use their money some other way needs to be increased.

DAC countries have discussed the possibility of simplifying procedures in order to make it easier for recipients to deal with the large number of donor spigots. For example, one could imagine the donor community agreeing to utilise a developing country's own planning documents as a basis for project planning. To do this, however, it would be necessary for the recipient country to have such documents and to be willing to modify them in order to meet the minimum requirements of prudent donor decision-making.

Another example would be in the field of audit. There are now in many African countries reputable and well-experienced audit firms which could be called upon to audit aid projects. It would be important that the recipient government have an audit process which satisfied the minimum needs of most of the donor community. In such a case, it would be reasonable for the developing country to raise the issue with the donor community. similar progress might be made in the field of procurement.

Technical Assistance

One other aspect of assistance deserves special mention. This is the whole area of what is commonly called technical assistance. Including free- 
standing technical assistance, amounts associated with capital projects and amounts provided by NGOs, the total technical assistance effort in SubSaharan Africa would be measured in billiors of dollars. Technical assistance plays a critical role in the training of people and in the provision of expertise. But, because it is provided from a multitude of sources in small amounts and because it gains even less attention from the fragile coordination mechanisms of the recipient governments, there is the danger that technical assistance may not be achieving all that we would hope for. Many African countries have become increasingly concerned by the apparent difficulty in achieving more self-sufficiency in the operation of government. Expatriates often continue in decision-making positions long after independence. One finance secretary, in talking about technical. assistance, said to me that there are two kinds of iong-term consultants he worries about. First, he corries about long-term incompetent consultants - those individuals who turn out not to be right for the job they were brought to do. Everyone agrees that they are not needed. But the other kind of consultants he worries about are the excellent ones who come into a ministry, do a fine job and then leave without having changed the capacity of his own country.'s people to do the job themselves. ye argued for long-term relationships with institutions in the cionor country where he could go from time to time for short-term advisory services of the highest calibre. This would cost less and be more effective in building the capacity to make decisions among his own officers. However, this finance secretary went on to say that in his government only a few ministries had strong enough leadership to make good use of such institutional relationships.

It would, of course, be wrong to conclude that all long-term consultants should be eliminated. Rather. I would ask whether the time has not come for technical assistance to be taken more seriously. Does it not serve the benefits of a carefully thought-thrcugh goverment policy? Does it not deserve much more programing attention in which the cbjectives of the assistance are carefully thought about? Might we not want to organise technical assistance behind more significant institution building kinds of objectives in which the dcnor and the recipient institutions enter into longer-term undertakings which would lead to attainment of self-sufficiency? 
It has been often stated that one way of achieving technical assistance programming which is more oriented to institution building would be to base such programming on carefully thought-through sector or sub-sector plans. These are often not available but the question must be raised as to whether it would not be worth the investment of time and planning staff - and-yesdonor help - to consider sub-sectors in these more strategic terms.

Let me take the example of agricultural research. In many countries there is a recognised need for more agricultural research, yet there is lacking an inventory of all that is currently being undertaken. Research institutions doing the same thing are separately seeking funds from outside sources. Operating as separate cells, they are not getting the benefits of networking among themselves. There is lacking a national research strategy. Vertical agencies are uncoordinated in particular geographic regions. A strategic planning process within a ministry of agriculture, involving the research facilities of the country along with the agricultural education facilities and the agricultural extension facilities resulting in a talked-through sub-sector strategy for agricultural research, would provide the basis for more efficient use of national resources as well as better coordinated technical assistance. If, in a particular country, the donors most interested in helping in this area were involved in the subsector planning process they would be more likely to support the result and, furthermore, might well make substantive contributions based on their experience in other countries. With a series of sub-sector strategies for critical areas, there would be a basis for organising technical assistance to achieve more important results more efficiently and to tailor the technical assistance to an institution-building mode rather than simply to proviae on-the-spot advice on a current basis.

One advantage of sub-sector strategies is their potential for raising sub-sector goals to the political level. It is hard to get the attention of the public and/or the government administration to such general goals as "improving research" or "improving health". But sub-sector campaigns to "double wheat production" or "increase immunisation levels to 75 per cent" have provided an organising vehicle to top management in many countries. While care must be taken to avoid one goal driving out others which may 
be less quantifiable but even more important, often the careful articulation of very precise objectives has made possible significant achievements at surprisingly low cost. While most sub-sector strategies could not be suitably organised behind such specific goals, it is worth looking for opportunities.

We should recognise, of course, that individuals on both the recipient side and donor side often see benefits in the present anarchy. Recipient institutions accept technical assistance for the vehicie or equipment which come with it - or salary topping and travel and study opportunities. Donor personnel are often creating their own jobs. Consulting firms seek business. The point is that these private objectives need to be controlled in the public interests of recipient governments and donors alike. It will be for the recipients to take the lead in improving technical assistance programming. I believe donors are willing to cooperate.

\section{Conclusions}

With these general comments, let me suggest some measures which fifrican governments and donors might work together to implement.

(1) Both donor and recipient communities should act within the framework of structural adjustment programmes where they exist. Rolling threeyear investment schedules which may have been adopted should be respected. Where developing country ministries or donors wish to sponsor projects to be included in the next revision of the investment schedule, the process of project priority setting should be transparent so that the cabinet anci head of state will be able to make decisions with maximum information on the table.

(2) Donors should continually review the opportunities to respond to structural adjustment programmes with quick-disbursing funds. Recipients should actively seek higher priority in oonor pertfolios for funding needed to support structural adjustment. Where projects are agreed to be appropriate, opportunities to finance them in ways which take account of on-going structural adjustinent measures should be sought. For example, in times of budget and foreign exchange stringency it 
may be appropriate for donors to finance a higher than usual proportion of local costs. For poorer countries grant or very concessional terms are more appropriate. Where existing capacity is not being well used or maintained, priority should be given to maintenance and spare parts and raw matorials.

(3). African governments should call to the attention of the donor community information on the impact of structural adjustment on education, health, population, nutrition and environment programmes. While solutions may not be easy, information and dialogue could lead to improved strategies and more support in these areas.

(4) Recipients and donors should work together to make Consultative Group and Round Table processes more effective. But these are only an aspect of the total process of dialogue and coordination. Recipients should welcome coordination efforts among donors and afford opportunities for donors to discuss issues frankly. While exchange of information should be encouraged, this is only one aspect of coordination. In the end, decisions must be made among alternative policies or programmes and the recipient governments must make these decisions.

(5) African governments, as a measure to achieve greater control over the use of scarce resources, should each decide to give a higher priority to the aid process. They should appoint one highly-placed person of exceptional ability to be in charge of aid. This person should have staff resources. He or she should operate in very close coordination with other ministries and especially with finance and planning and should nave airect access to the cabinet. All aid should be coordinated by this officer. While negotiation on small aid programmes could be delegated to other ministries, all aid should be required to operate within government policy. No project should be approved unless its financial implications, both during implementation and subsequent operational phases, have been considered by budget and planning authorities. All donors should either deal with the aid coordinator or be specifically authorised to deal with another ministry which in 
$\mathrm{ECA} / \mathrm{CERAD} / 87 / 20$

Page 18

turn would be expected to operate within established policies and to keep the coordinating unit fully informed. African governments should develop cadres of trained aid negotiators - people who understand the legal and policy issues and know donors" procedures and negotiating goals. Donors are willing to finance the training of aid-negotiating staff.

(6) African governments should insist that each technical assistance intervention be planned with a clear objective in mind. "This should usually be an institution-building objective which will increase selfsufficiency。

(7) As rapidly as possible, where they do not already exist, sub-sector strategies should be articulated as a framework within which both country and donor programmes can operate. These should be undertaken with the cooperation of donors to the sub-sector. Long-term goals should be clearly stated and measures designed to reach them. Sub-sector strategies should be designed within the framework of budget realities, with needed attention to cost recovery and decentralised responsibility.

In summary, there is consensus that African countries face difficult structural adjustment issues and that support is needed for the bold efforts now being implemented. In addition to improvements in the world economic environment, donors can help by debt relief measures, provision of aid which supports structural adjustment efforts and an increased volume of aid. Recipients can help by improving aid decision-making. Proper measures of discipline, and flexibility are needed by all sides. With dialogue on these matters increasing there is reason to hope that significant progress will take place in the coming years. 


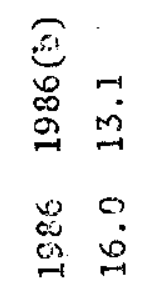

$$
\begin{aligned}
& \text { in } \quad \text { is }
\end{aligned}
$$

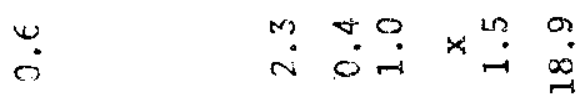

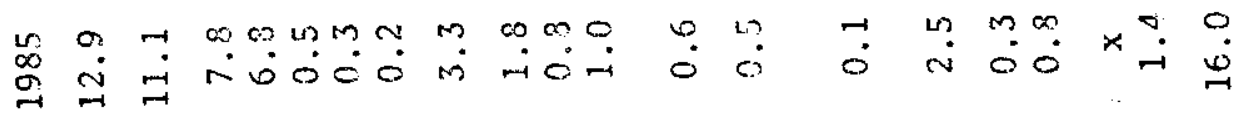

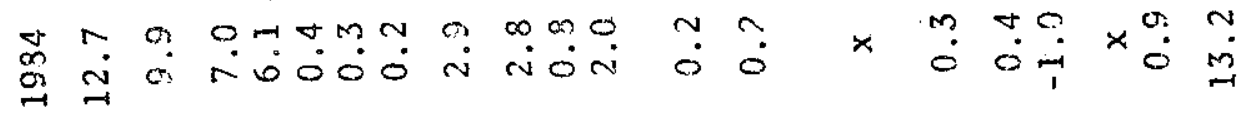

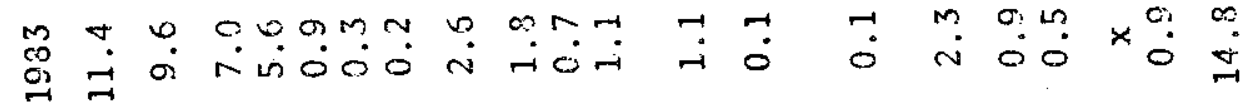

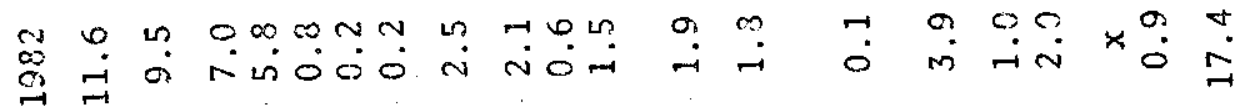

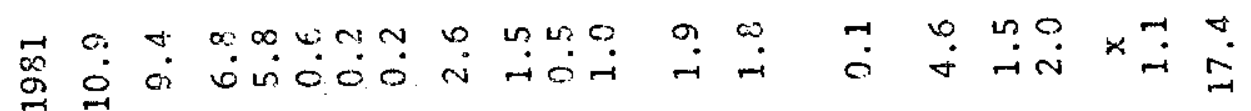

\section{岂}

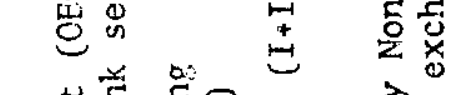




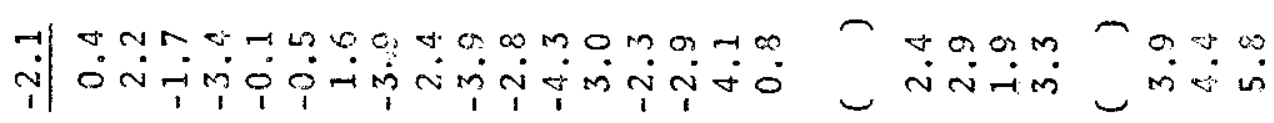
$z_{2}$ ॠ

(

00

त.

艛

过

:.

in

కـ

$m$, ,

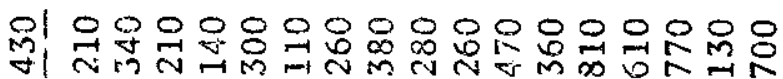

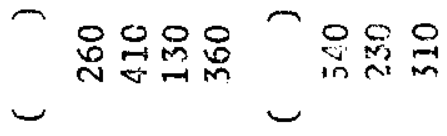

$-1 m$

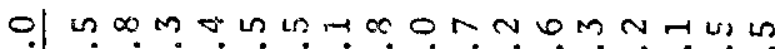

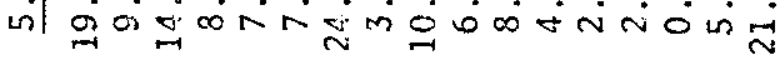

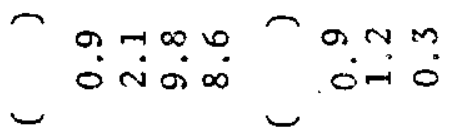

7 0 on

级 至

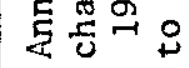

गे

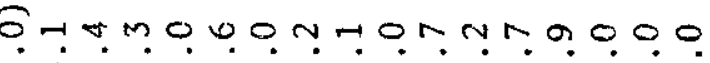
ن

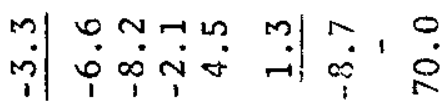

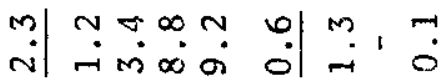

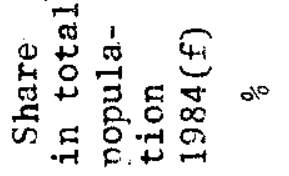

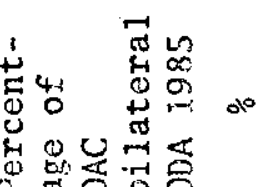

告

$\dot{-1}$

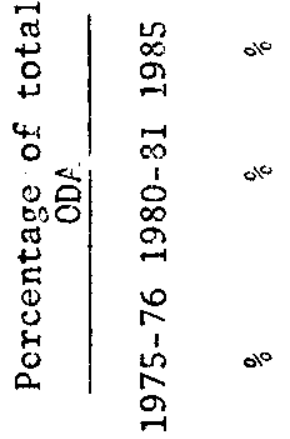

.

n| $N M$ M क|

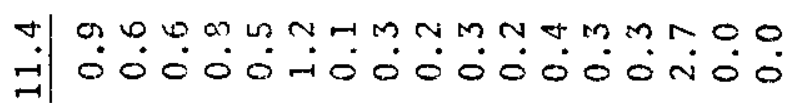

\&

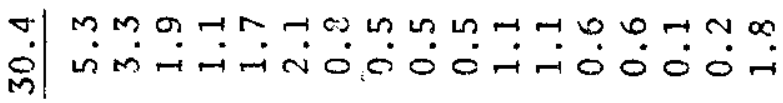

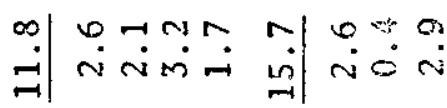

9. $0,0,4+2$.

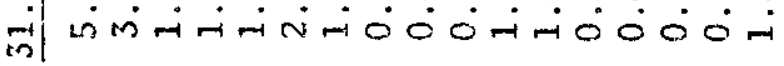

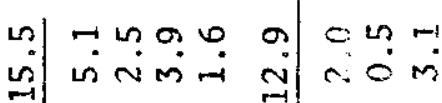

N|

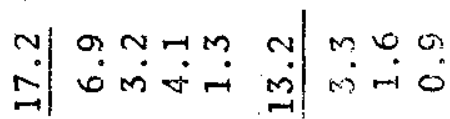

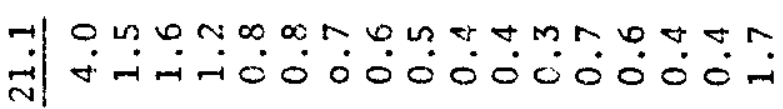

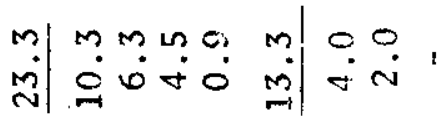

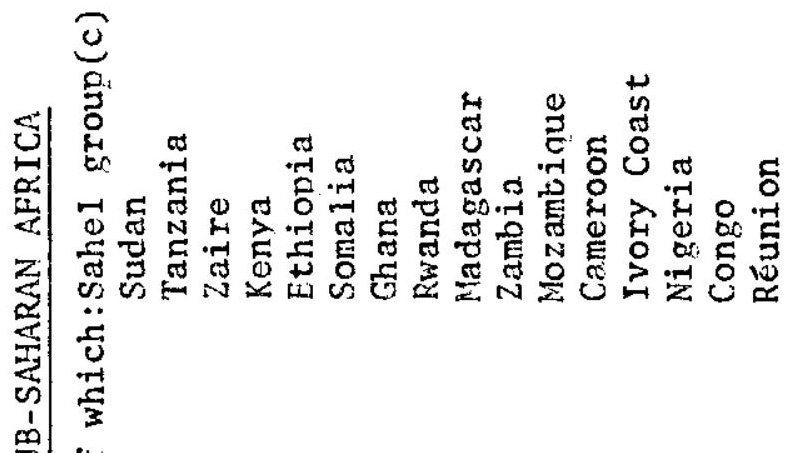




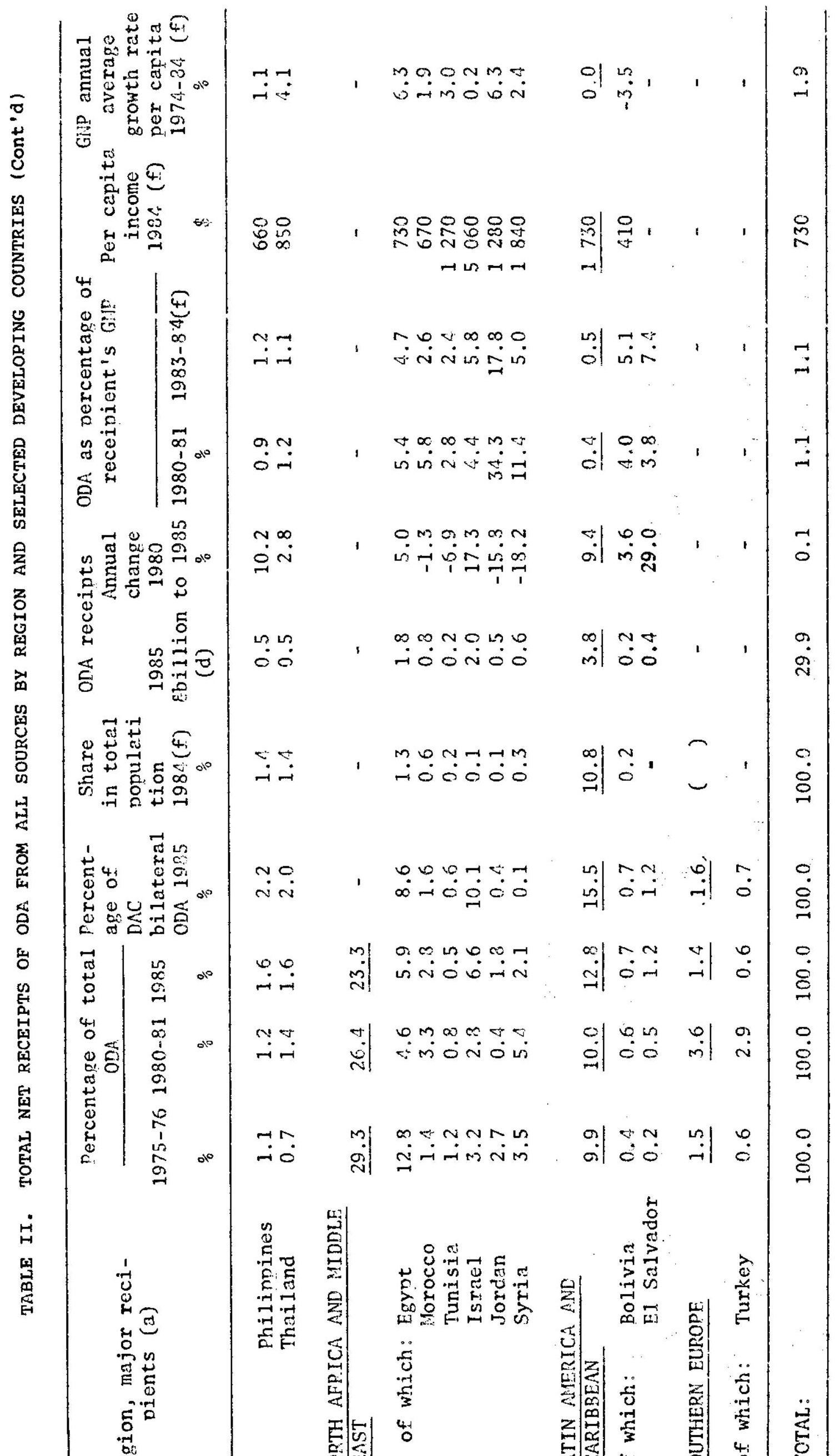


ECA/CERAD/87/20

Page 22

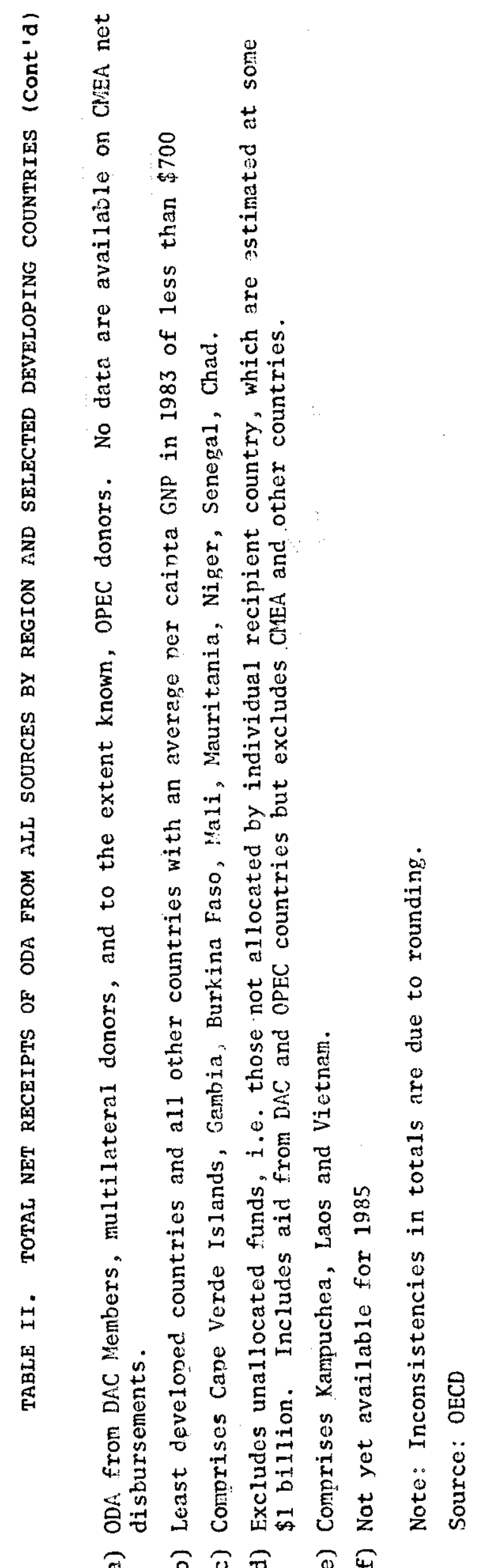




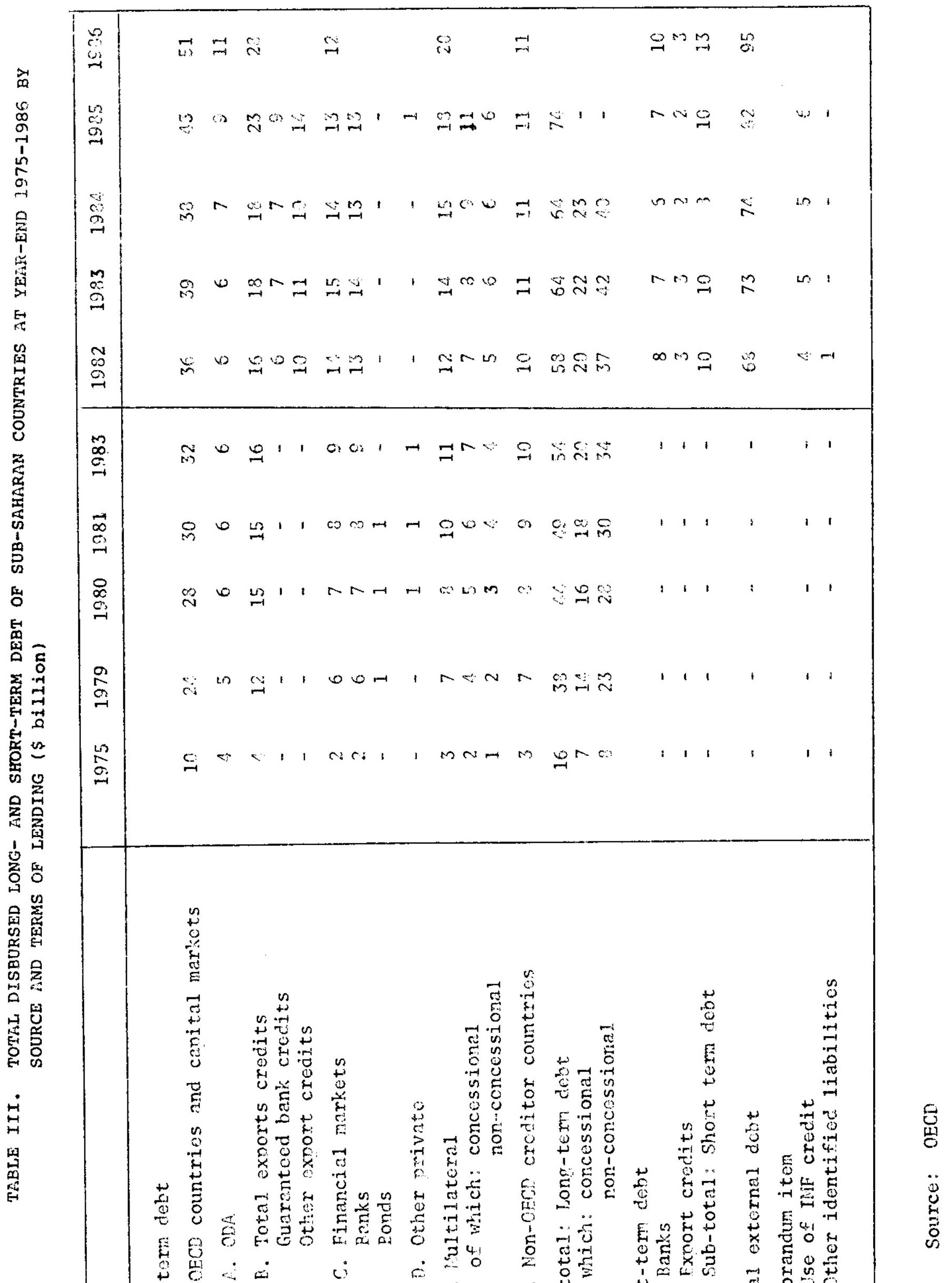




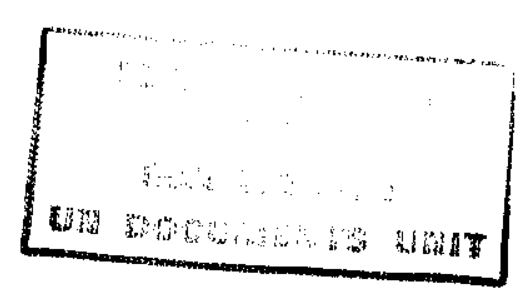

$\mathrm{ECA} / \mathrm{CERAD} / 87 / 20$

Appendix 1

Appendix 1

AID FOR IMPROVED DEVELOPMENT POLICIES AND

RELATED ASPECTS OF AID CO-ORDINATION

1. INTRODUCTION

The need to use aid more systematically to support improved development policies and programmes of developing countries and the related problems of aid co-ordination has for some time been a central theme in the work of the Development Assistance Committee. This work is an essential element of the efforts of DAC Members to improve the efiectiveness of aid in achieving development goals and objectives. At the Development Assistance Committee's High-Level. Meeting held in December, Members reviewed recent work on this subject and approved a scries of guiding principles designed to give general guidance and direction to a collective effort at improved aid coordination with developing countries. The text of these guiding principles and the considerations which led to their adoption is set out in the section that follows. The remainder of the chapter provides a factual account of recent developments, which form the background from which these conclusions have emerged.

\section{CONCLUSIONS OF THE DAC HIGH-LEVEL MEETINE OF 1986}

The Nature of the Problem

Much of recent DAC work has been concerned with the problems of adapting aid to support improved development policies by developing countries and the related problems of aid co-ordination. These problems were summarised in Twenty-Five Years of Development Co-operation: A Review along the following lines.

The number of development assistance institutions operating in developing countries has expanded substantially in recent years. Two dozen donor governments, some ten multilateral development banks and funds, 19 United Nations agencies and several hundred non-governnental organisations currently provide development assistance. Some donors use more than one administrative unit to channe1 aid funds to recipient countries. Additionally, export credit agencies and comercial banks provide finance to countries they judge to be creditworthy. 
The funds made available from external sources vary greatly as to their financial terms and other conditions (procurement regulations, enduse controls, counterpart requirements, etc.). Donor preferences for particular sectors, projects and approaches are also often different. In addition, there are differences anong donors in their willingness to provide certain kinds of aid, and in the degree of their involvement in managing the aid delivery process. Several donors maintain full-time field staffs in recipient countries to administer aid programmes. Others work mainly through resident diplomatic missions, augmented in some cases by regional aid offices and in all cases by visiting development specialists.

Adding further to the complexity of the aid process is the wide variety of needs for aid to help finance capital projects in many different sectors involving different planning and executing arencies; to provide technical assistance for strengthening local ranagement, research, training and other institutions; and to provide funds for essential imports, such as fuel, other production goods, spare parts and, in some cases, food.

To ensure that this complex process, involving divergent sources and diverse activities, interrelates effectively with the recipient country's own resources and programming processes requires an extraordinary organisational effort. Frequent donor-recipient consultations on policy and procedural issues are required to establish agreed purposes approaches, administrative systems and supporting measures for each aid project or programme.

Aid effectiveness has been impaired in a number of instances where a recipient's limited planning or administrative capacity was unequal to the demands of aid manegenent. In some cases the aid received may have been substantial in the aggregate but nonetheless short of the critical mass because of insufficiently concerted planning and concentration of resources.

Moreover, experience has shown that for aid to make a lasting contribution to the economic and social well-being of developirg countries it must be concerned not only with the proper selection, design and implementation of individual projects and their economic and institutional sustainability but also with the support of broader sectoral and national efforts and policies.

Policy decisions cannot and should not be imposed from outside. Donors must strive to understanc the political, institutional, economic and social considerations that affect the recipient's capacity to undertake policy adjustments. Closer working relations and co-operation are most likely to evolve from intimate donor knowledge of the political and socio-economic context of the recipient country and from the provision of aid on an increasingly assured, continuous and predictable basis.

For donor advice in the policy and programing dialogue to be credible, it must be consistent as well as competenc and reflect full understanding 
ECA/CERAD $/ 87 / 20$
Appendix 1
Page 3

of the variaty of economic and other constraints facing the developing country. A profusion of conflicting advice from a muitiplicity of donors can be counterproductive. Policy reform efforts are most likely to be fruitful when they are concentrated on key problem areas and when the responsible authorities - central and sectoral - assume responsibility for policy analysis and decisions. It is a basically unhealthy situation if developing countries have to rely heavily and repeatedly on donors to carry out theix policy analyses and programme planning.

Guiding Principles for Aid Co-ordination with Developing Countries

It is against the background of the above considerations that DAC Members have, at their 1986 High-Level Meeting, adopted the following principles. These principles must be used flexibly to meet the diversity of specific situations; they apply mainly to developing countries which depend heavily on external assistance and need the support of international aid co-ordination arrangements to ensure effective use of resources. DAC Members recognise that developing countries themsalves are responsible for setting their policies and priorities and that central responsibility for aid co-ordination lies with each recipient government.

i) Donor Co-operation to Help Developing Countries Establish and Implement Improved Policies and Carefully Appraised Investments and Expenditure Programmes

Developing countries need well-designed policies and carefully appraised investment and expenditure programes for effective and co-ordinated use of both their national and external resources.

DAC Members recognise the importance of the World Bank/IMF-led process of working with developing countries in the articulation of structural adjustment programmes. They welcome the recent shift in the orientation of structural adjustment programmes toward growth. They agree that structural adjustment programmes should take fully into account equity and income distribution issues and would like to see more explicit addressing of budget and strategy issues in human resources questions such as education, health and population, as well as environment. They note that structural adjustment programmes can maice a contribution to creating the conditions which in the medium term may encourage a resumption of private flows to developing countries.

DAC Members underline the need for aid agencies to help developing countries strengthen their analytical and management capacity to design and implement effective policies and programmes. DAC Members also recognise the need for greater participation by bilateral aid agencies in assisting developing countries in their efforts to improve their policies and programmes and providing the often costly preparatory analytical work. While multilateral agencies are well placed to assist in this field, bilateral donors a1so have a role to play, especially at the level of sectors where they have special expertise to offer. DAC Members will review the need to strengthen their capacity to make contributions in this area. 
$\mathrm{ECA} / \mathrm{CERAD} / 87 / 20$

Appendix 1

Page 4

DAC Menbers emphasize the need for continuing discipline by both recipients and donors in adhering to carefully appraised and productive investment programmes. Such programmes will provide a particularly useful basis for aid allocations if they have been the subject of careftil review and discussion with donors with the help and advice of the international financial institutions. The regular review of these programmes offers an opportunity to examine progress and to consult on priorities. They are a good basis for aid co-ordination.

DAC Members acknowledge the desirability of providing adequate financing to developing countries undertaking effective policy reform efforts. This will often require making available quick-disbursing funds for the financing of urgent import requirements. Indications by donors of medium-term funding prospects will facilitate structural reform efforts and will in turn be facilitated by such efforts.

There is a need to put more emphasis, in the period immediately ahead, on rehabilitation and improved use of existing capacity. Programmes for these purposes will often have a higher priority than launching large new projects. DAC Members recognise the need to make realistic provision for recurrent cost and maintenance recuirements but with agreement for step-by-step advance towards self-reliance.

DAC Members recognise the special merits of having several donors work together with a recipient government in the co-financing of important projects and sector programmes. They will attempt to reduce administrative burdens by relying as much as possible for appraisal on a bilateral or multilaterai lead agency.

Export credits may in selective cases be helpful also in the low-income countries but great care must be exercised to ensure that development goals and the discipline of carefully appraised investment programmes are taken fully inte account.

External debt servicing obligations have major financing implications for many countries. Debt relief exercise by the Paris Club should be based on full information of the nature and requirements of growth-oriented medium-term structural policy reform efforts.

ii) Further Steps to Improve Arrangements for Aid Co-ordination

DAC Members reaffirm their determination to co-operate closely with recipient countries, international institutions and other donors in international aid co-crdination arrangements working towards operationally relevant conclusions, based on genuine consensus. 
ECA/CERAD $/ 87 / 20$

Appendix 1

Page 5

DAC Members accept the need for close co-operation between recipient governments and the multilateral leaci agencies but feel that the processes of consultation and co-ordination should provide an opportunity for bilateral donors to express their views during the formative stages of policy and programme consultations between recipients and the international agencies.

Full and franik exchanges of pertinent information on on-going and planned activities awong donors, and between donors and recinis ents, are essential to the successful co-ordination and effective use of aid.

DAC Members appreciate the recent improvements in the organisation of Consultative Groups and Round Tables and invite the lead agencies to pursue their efforts in the following directions:

- Encouraging greater participation by bilateral donors in the consultations preceding Consultative Group and Round Table meetings making use of local groups where possible; such participation is essential to enure the emergence of a genuine consensus on recipient country development policies and programmes;

- Revising the format of Consultative Group meetings to facilitate more frank and substantive exchanges of views on key policy issues and problems; more careful review of recipient investment plans with a sharper focus on sectoral policies and investment programmes; fuller discussion of the aid implications of recipient structural adjustment programmes; and taking inte account al1 elements determining recipients' overall financial situation, including trade prospects and debt service requirements;

- To be more concerned with the identification and programing of technical assistance needs and priorities which are often as important as financial needs; the UNDP has a special role to play in this regard and should participate fully in the Consultative Group processes;

- Recording of conclusions reached at Consultative Group and Round Table meetings, as sumnarised by the Chairman, in a detailed and action-oriented manner, and making them available promptly to interested parties including local co-ordination groups;

- Ensuring effective follow-up with respect to actions steming from Consultative Group and Round Table meetings, specitically regarding donor statements of aid intentions and recipient statements of policy reform intenitions through, inter alia, sectoral and other in-country meetings.

DAC Members are encouraged by the UNDP's recent progress in strengthening the Round Table process and enhancing its capacity to perform its co-ordination role more effectively through, inter alia: encouraging developing countries to participate actively; emphasis on policy reforms: 
$\mathrm{ECA} / \mathrm{CERAD} / 87 / 20$

Appendix 1

Page 6

the strengthening of UNDP staff; a more seiective approach to the choice of countries and participants; inprored anaiysis and in-country follow-up; better preparation and organisation of the Round $T a b l e$ meetings through closer colla'vration with the Wowld Bank; encouraging adequate reprsentation by recipients and donors, and with UND? chairmanship of the meeting. Round Tables can be further strengthened if, in the first phase of the process, UN specialised agencies caii be representer by the UNDP and if DAC Members' representativ reflec this position in the appropriate bodies of the specialised agencies.

It was recognised that the serond phase of the Round Table process, i.e. the larger and more open iseting at the country level, can be particularly useful in confirming the sesolve of the governnent to push ahead with its adjustment policies by providing it with on opportunity to indicate its policy commitments in a broad seting Donors in turn have an opportunity to announce their support for the potoranme.

DAC Members underline the near to strenghen aid co-ordination at the local (i.e. recipient country arital) level, and to establish stronger links between central and local comidinitiou armargements. Central coordination arrangements should give the lear to local and sectoral coordination, inter alia, by ideatifyins ssctes to be aduressed at the local/sectoral level. Policy diaicgue should be an intrinsic element of aid comordination at the 10ca-isectora? levelo Recipient governments should be at the centre of the process. TFe paricipation of appropirate officials from the recipient government"s line agencies is essential, but for decisions reached on "ctor ait pulicies ot programes it is important for the government's central firroe and plonning authorities to be involved.

There has been considerable axnonsion of rocel comordination activities rconty. Frogress hit beer mase st the Ievei of exchange of information, avoiding project cuplication and promoting joint activities; but more needs to be done, esperizlly relating aid to carefully appraised and reviewed investmen: ponzonmes, snd developing and implementing sector policies and rrogromes. DAf Monicens velcome the establishment of recipient-led locel mechanisns to the prose of ensurirg more

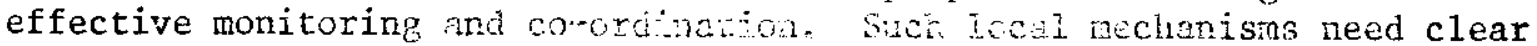
mandates.

DAC Members siress the ingotece of trfored scctoral approaches, involving the preparation of aid upovt tor arefuily uppraised investment and expenditure progranes takts bitut and recuraten cost financing prospects realistically into acour. here je also the need to explore prospects for rore sector fronofie ve esjecunc (borh technical and capital)

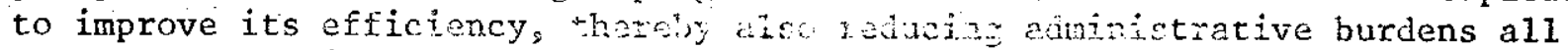
around through improved work sharing and tararization of procedures. An important tool to achieve thic ciecte is the use of aid corfinancing arrangements. 
$\mathrm{ECA} / \mathrm{CERAD} / 87 / 20$

Appendix 1

Page 7

DAC Members acknowledge the need for sreater involvement of the regional development banks in policy dinlape and reform, particularly at the sector level, when they are important donors. It is important that they work within the macro-econonic policy frameworks and co-operate closely with the World Bank or the UNDP, as appropiate.

Rezional approaches to co-ordination, as they have been evolved particularly in Africa within the franework of CILSS/Club du Sahel and SADCC, looking at aid needs in a regional context and encouraging regional co-operation, can be an essential complement to country-1evel co-ordination.

DAC Members are fully aware of the need to avoid everburdening the administrative capacity of recipients. While effective action to streanline the administration of aid will not be easy, they will seek opportunities to harmonize and simplify the requirements they exact from recipient governments, especially by making greater use of studies and reports already prepared by thers or worked out by an asceed lead agency. This may entail modifications to legislative and administrative requirenents.

DAC Members recognise the staff implications of improved co-ordination, particularly the need to have staff of appropriate economic and nolicy expertise in support of this function. Effective participation both in the policy dial gue and in aid proyrarming at the local level will be facilitated by the presence of policy-oriented staff stationed in recipient ccuntries in which individual Members have major aid interest. This may require strengthening the staff in the field, including the redeployins of some staff, adjustments in personnel training and recruitient policies and effective use of private expertise.

DAC Members underline the essentiality of strenthening developing countries' institutional capacity to design and implement effective policies and programmes and to manage their development processes. Competent central government institutions are essential to establish an effective policy framework, but broader institutional develoment efforts are required at all levels of government, including sectoral and locnl levels. These efforts should also take into account the capabilities and potential of the private sector and the requirements it has for institutional development to better enable it to make its full contribution.

DAC Members will take appropriate action within their cwn organisations to implement the princifles set out above. They will from time to time take stock in the $\mathrm{DAC}$ of the progress being made. 